Management control in inter-organizational relationships: Lessons learnt from public-private partnerships

Martine Cools, Regine Slagmulder, Alexandra Van den Abbeele

DEPARTMENT OF ACCOUNTANCY, FINANCE AND INSURANCE (AFI) 


\title{
Management control in inter-organizational relationships: \\ Lessons learnt from public-private partnerships
}

\author{
Martine Cools \\ Lessius - Katholieke Universiteit Leuven \& \\ Rotterdam School of Management, Erasmus University Rotterdam \\ Lessius, Korte Nieuwstraat 33, B-2000, Antwerpen, Belgium \\ martine.cools@lessius.eu
}

Regine Slagmulder

Vlerick Leuven Gent Management School

Reep 1, 9000 Gent, Belgium

regine.slagmulder@vlerick.be

\begin{abstract}
Alexandra Van den Abbeele *
Katholieke Universiteit Leuven

Department of Accounting, Finance \& Insurance

Naamsestraat 69, 3000 Leuven, Belgium

alexandra.vandenabbeele@econ.kuleuven.be
\end{abstract}

${ }^{*}$ Corresponding author 


\title{
Management control in inter-organizational relationships: \\ Lessons learnt from public-private partnerships
}

\begin{abstract}
Public-private partnerships (PPPs) have become increasingly common. However, reported failure rates are high, underlining the challenge to effectively govern such relationships. The purpose of this paper is to empirically investigate the management control structure for different types of PPPs by adopting a comparative case study approach. The two cases under study are partnerships between municipalities and their private partners: a long-term infrastructure project and an urban regeneration project. Given the different nature of the activities and the accompanying risks, the PPP literature suggests that the cooperation in these PPPs is organized in very different ways, namely loose versus tight. We propose (1) that outcome-based control mechanisms play an important role in managing loosely organized PPP projects and (2) that behaviour and social control mechanisms play an important role in managing tightly organized PPP projects. Although our results support these propositions, our analysis also suggests that existing frameworks for private inter-organizational relationships (IORs) are insufficient for explaining governance structures in PPPs. Given the specific nature of PPP arrangements, we identify a number of socio-political risks and related management control mechanisms not typically discussed in theories of private IORs. More specifically, we conclude that conveners and project champions play an important role as political controls in the success of PPPs.
\end{abstract}

Keywords: inter-organizational management control, public-private partnerships, socio-political risks, political controls 


\section{Introduction}

Public private partnerships (PPPs) have become common in recent years as public organizations increasingly enter into relationships with private partners in order to benefit from private sector techniques such as performance contracting and consumer responsiveness in service delivery (Bloomfield, 2006; Broadbent and Laughlin, 2003; Hood, 1991, 1995; Warner and Hefetz, 2008). While PPP arrangements cover a variety of transactions (Grimsey and Lewis, 2005; OECD, 2008), they are generally defined as cooperative arrangements between the public and private sectors that involve the sharing of resources, risks, responsibilities, and rewards with others for the achievement of joint objectives (Kwak et al., 2009). PPPs can thus be considered as a hybrid type of arrangement that fills a space between traditionally procured government projects and full privatization (Grimsey and Lewis, 2005). Various sources report that PPPs are no straightforward success (Babiak 2009; Kwak et al., 2009; Johnston and Gudergan, 2007) as many PPP projects are either held up or terminated due to a variety of institutional and strategic barriers (Klijn and Teisman, 2003; Bloomfield, 2006). Since the public partner retains the liability to ensure the performance of any duty towards the community it serves, PPP arrangements must contain appropriate governance structures to ensure adequate performance and to minimize the risks associated with using private partner contractors in a public sector environment (Torres and Pina, 2001). Similarly, the private party strives for successful cooperation that achieves its performance goals.

While the choice for adequate governance structures is recognized as one of the most important difficulties of PPP initiatives (Johnston and Gudergan, 2007; Torres and Pina, 2001; Warner and Hefetz, 2008), few papers have thoroughly studied the governance choices made in PPPs. More research on governance structures in PPPs has recently been called for (Hodge and Greve, 2007; Bloomfield, 2006; Johnston and Gudergan, 2007). In this paper, we investigate the management control structures for the governance of different PPPs by adopting a comparative case study method involving two PPP arrangements. We hereby consider the perspective of both the public and the private partners involved in the dyad.

As a starting point, we take the management control framework developed by Das \& Teng (2001). This framework has been extensively applied to study the management control structures for private inter-organizational relationships (IORs), such as outsourcing relationships, supply chain relationships, joint ventures and alliances (e.g. Anderson \& Dekker, 2005; Dekker, 2003; Dekker, 2004; Kamminga \& van der Meer-Kooistra, 2007; Langfield-Smith, 2008; Langfield-Smith \& Smith, 2003; van der Meer-Kooistra \& Vosselman, 2000; Vosselman \& van der Meer-Kooistra, 2006). These studies discuss relational and performance risks as the two primary risks in IORs (Das and Teng, 1996; 2001). Relational risk addresses the possibility and the consequence that the partners in an IOR do not have the willingness to fully commit themselves to joint efforts and mutual interests. Performance risk accounts for situations where, despite the willingness to fully cooperate, the partners lack the ability to successfully achieve the objectives of the IOR. To govern these risks, the IOR literature discusses how organizations 
rely on different types of control such as outcome, behaviour and social control (Das and Teng, 2001; Ouchi, 1979).

However, besides relational and performance risks PPPs also face socio-political risk (Abednego and Ogunlana, 2006; Babiak, 2009; Bloomfield, 2006; Brignall and Modell, 2000; Dorado and Vaz, 2003; Hodge \& Greve 2007; Johnston and Gudergan, 2007; OECD, 2008). Socio-political risk derives from political obstacles caused by the need of public organizations to respond to other parties such as the community they serve, stakeholder groups, political parties, donors or hierarchically superior government agencies (Dorado and Vaz, 2003; Jennings and Krane, 1994). Socio-political risk is thus distinct from relational risk because it does not depend on willingness to commit to the relationship, and from performance risk because it is not caused by a lack of ability. We therefore extend the framework by Das and Teng (2001), which has been extensively applied to private IORs, by introducing socio-political risk along with performance and relational risks.

The public administration literature suggests that socio-political risk may be far more difficult to control than relational and performance risks (Johnston and Gudergan, 2007). In addition, we expect that socio-political risk may interact with relational and performance risk as it may amplify or minimize the differences in mission, professional orientation, structures and processes between public and private partners, and thus may further complicate PPP governance (Abednego and Ogunlana, 2006; Babiak, 2009; Dorado and Vaz, 2003; Jennings and Krane, 1994). Given the influence of these three types of risk, we propose that the management control framework by Das \& Teng (2001) is insufficient to fully explain management control structures in different types of PPP projects. Although outcome, behaviour and social control might help reducing socio-political risks, the public sector literature, inspired by the project management literature, points at other mechanisms that are important to reduce socio-political risks in public settings. More specifically, this literature stresses the role of influential personalities and their persuasion, mutual influence and leadership skills to overcome socio-political risk (Dorado and Vaz, 2003; Selsky and Parker, 2005).These individuals are called project champions and conveners, depending on whether they are part of the organization or come in as a third party. Project champions are individuals involved as a partner in the project, who are able to contribute to the success of the project by using and developing informal systems of relationships (Schön, 1963). Third party conveners, also called 'bridging persons', are defined as catalytic agents who are able to convince unaware, unsure or sceptical actors to engage into the cooperation (Dorado and Vaz, 2003; Kalegaonkar and Brown, 2000). We introduce project champions and conveners in our management control framework as political control mechanisms, in the sense that they are able to respond to the diverse and changing expectations of political and community stakeholders (Mellors 1996, Dunoon 2002). Apart from their contribution to manage socio-political risk, we will also study the impact of these political control mechanisms on the other types of risks. 
To further explore the management control mechanisms used to mitigate different types of PPP risks, we undertook comparative case study research involving two successful PPPs. We deliberately selected different types of PPP arrangements which are, based on the nature of their activities, characterized by different levels of risks: a long-term infrastructure project and an urban regeneration project. Given the different nature of the activities and the accompanying risks, the PPP literature suggests that the cooperation in these PPPs is organized in very different ways, namely in loose versus in tight ways (Hodge and Greve, 2007). In a tightly organized PPP the public and private partners work together intensively during project execution, whereas in a loosely organized PPP the partners form loose networks of collaboration with a specified time limit. We build on the IOR management control framework of Das and Teng (2001) to propose (1) that outcome-based control mechanisms play a dominant role in managing loosely organized PPP projects and (2) that behaviour and social control mechanisms play a dominant role in managing tightly organized PPP projects. In addition, we also expect that (3) political controls will play a crucial role in managing the overall risk situation, particularly when taking into account the socio-political risks.

Our results indicate that in the loosely organized PPP (i.e. the long-term infrastructure project), the public party is able to clearly specify the problem and output requirements upfront and that outcome controls are explicitly mentioned in a long-term legal contract. As expected, we find that the management control structure in this PPP project is oriented relatively more towards outcome control than to behaviour and social controls. In contrast, for the tightly organized PPP (i.e. the urban regeneration project), we find that it is more difficult to clearly define the expected outcomes a priori, and that intensive cooperation is needed to bring the project to a successful end. Our expectation that the management control structure of this tightly organized type of PPP is oriented relatively more towards behaviour and social controls than to outcome controls, is again supported by our observations. Further, our results indicate that both PPPs rely on political control mechanisms to manage socio-political risk that are not typically discussed in private sector IOR frameworks. More specifically, we find that project champions and conveners play a crucial role in the success of these two - very different - PPPs.

Additionally, we observe how socio-political risks interact with relational and performance risk.

The main contribution of this paper is to extend the IOR management control framework developed by Das and Teng (2001) to public-private settings by incorporating socio-political risk and political controls. Given that the extant literature underestimates the role of socio-political risk in IORs, we suggest that these findings may also be relevant outside of the scope of PPP studies. At a more general level, we propose that political controls may play a role in the success of IORs that involve the cooperation among organizations with diverse objectives, structures and cultures.

The remainder of the paper is organized as follows. In the next section, we review the prior literature used to build up the theoretical framework and to formulate three research propositions. Section three explains the research method. Section four introduces the cases 
and presents the analysis of our data in line with our theoretical framework. The results are discussed and the research propositions are evaluated in section five. This final section also summarizes the conclusions, discusses the limitations and provides suggestions for future research.

\section{Theory and propositions}

In this section, we introduce the Das and Teng (2001) management control framework that studies control structures in private sector IOR settings. Next we discuss the nature of activities and accompanying risks for different types of PPPs. We expect that the Das \& Teng (2001) framework, with its focus on relational and performance risks and the related use of outcome, behaviour and social controls, may help explain governance structures for different types of PPPs. However, we also argue that the framework is insufficient to fully explain the governance of successful PPPs as it ignores socio-political risk. Finally, we review the public sector literature in order to discuss how socio-political risk can be governed in a public sector IOR setting. Based on this literature review, three propositions are developed. Figure 1 provides an overview of the theoretical framework drawn to guide the empirical analysis.

- Insert Figure 1 here -

\subsection{Risk and control in inter-organizational relationships}

In line with an extensive prior literature on IORs, we follow the management control framework for IORs developed by Das and Teng $(2001)$. Das and Teng $(1996,2001)$ state that the choice of governance type in IORs is dependent on the partners' estimation of relational risk and performance risk. While relational risk is concerned with whether the cooperation among partners will go smoothly, performance risk has to do with the hazards of not achieving the performance objectives of an IOR, given full cooperation by all partners (Das and Teng, 1996). In order to manage these two types of risks, partners in IORs rely on a broad set of management control mechanisms. The control literature suggests that there are three basic types of control (Das \& Teng, 2001; Eisenhardt, 1985; Ouchi, 1979): outcome control, behaviour control and social control. Outcome and behaviour control are formal controls that are externally specified and measured (Eisenhardt, 1985). While outcome controls specify and measure results to be achieved without interfering in the way in which the results are obtained, behaviour controls specify and measure desirable behaviours to achieve goals, without necessarily focusing on the extent of goal achievement. Social controls are not externally specified or measured. Instead the focus is on creating shared values, beliefs and goals among the partners in the IOR so that appropriate behaviour will be reinforced and rewarded.

In Eisenhardt's (1985) conceptualization, the choice of control type depends on two task characteristics: the ability to measure outputs (i.e., the extent to which it is feasible to measure the desired performance with reasonable precision), and the knowledge of the transformation 
process (i.e., the extent to which means-ends relationships are clearly understood, also referred to as task programmability (Thompson, 1967)). Outcome control is preferred in situations with high output measurability and low task programmability. Behaviour control is expected to work best in the opposite situation, more precisely when output measurability is low but task programmability is high. Social or informal control relies on the socialization of individuals to achieve goal congruence and is exercised when both output measurability and knowledge of the transformation process are low. Here the focus is on developing shared values, beliefs, and goals so that appropriate behaviours are reinforced and commitment to achieve these goals is high. Together, these three types of control provide a useful and wide-spread typology to study the control mechanisms used to manage performance and relational risk in IORs (Das and Teng, 2001; Dekker and Van den Abbeele, 2009; Eisenhardt, 1985).

\subsection{Risk and control in different types of public-private partnerships}

Since high failure rates have been reported in the context of PPPs (Bloomfield, 2006; Johnston and Gudergan, 2007; Klijn and Teisman, 2003; Kwak et al., 2009), appropriate governance structures need to be developed to minimize the risks associated with using private partner contractors in a public sector environment (Torres and Pina, 2001). In this subsection, we discuss different types of PPP activities and the related risks, as well as the mechanisms installed to control them.

\subsubsection{Nature of PPP activities and related risks}

PPP arrangements include a wide range of activities, ranging from rather simple market transactions to sophisticated and far-reaching cooperation (Hodge and Greve, 2007; Kwak et al., 2009). Depending on which of the partners is considered to be best placed to manage the risk involved in certain project activities, more or less activities are added to the responsibilities of the private partner (Grimsey and Lewis, 2005; OECD, 2008).

At one end of the risk-spectrum are the so-called Design and Build (DB) arrangements, where the private partner is responsible for the design and construction of the project for a specified time before handing it over to the public sector. DB projects often involve public procurement with little or no private financing so that the public sector bears almost all risks (OECD, 2008). This type of cooperation is usually found in urban regeneration projects, which combine measures for improving the living environment and/or housing and measures aimed at strengthening the local economy (Klijn et al. 2008). DB projects typically involve intensive interaction because the various project components, usually the domain of diverse private and public actors, have to be coordinated. This intensive interaction and joint decision making require clear working procedures and frequent meetings to coordinate the tasks. In this type of PPP it is often difficult to clearly delineate in advance the outcomes and ambitions of the cooperation (Klijn et al, 2008). The output measurability for this type of PPPs is thus low, while 
the knowledge of the transformation process for both the public and the private partner is medium to high (Eisenhardt, 1985).

At the other end of the risk-spectrum we find the Design Build Finance Maintain and Operate (DBFMO) projects, in which the private sector partner is fully responsible for designing, building, financing, maintaining and operating the project. The private partner is given the right to operate, often for an extended period, a service traditionally undertaken by the public party alone (Grimsey and Lewis, 2005). Price regulation is possible (OECD, 2008) and the private sector partner is paid for the delivery of the services to specified levels. Importantly, the private sector must bear the risks of achieving the service specifications (Grimsey and Lewis, 2005). This implies an almost $100 \%$ risk transfer to the private sector (OECD 2008). Typical DBFMO projects involve long-term infrastructure projects, which may encompass the design and construction of substantial capital assets along with the provision of a range of services and the financing of the entire construction and operation (Grimsey and Lewis, 2005). The private sector partner must provide all the managerial, financial and technical resources needed to achieve the required standards (Grimsey and Lewis, 2005). As performance standards are explicitly specified, the output measurability for this type of PPPs is high, while the knowledge of the transformation process lies predominantly with the private partner (Eisenhardt, 1989).

In order to gain insights in the control structure of diverse PPP arrangements, the discussion that follows focuses on the two extremes. An urban regeneration project, as a common arrangement of the DB type, will be contrasted with a long-term infrastructure project representing a typical DBFMO arrangement. The degree to which activities and related risks are shifted between public and private parties will affect relational and performance risks experienced in these public-private IORs (Das and Teng, 1996, 2001). As explained above, urban regeneration projects require intensive interaction between the public and the private actors. The output measurability for this type of PPPs is thus low, while the knowledge of the transformation process can be medium to high (Eisenhardt, 1985). As a result, the process will involve a significant relational risk (Das and Teng, 2001). At the same time, even though it is hard to concretely define the desired result of an urban regeneration project in advance, performance risk stays a significant issue. In contrast, long-term infrastructure projects start from clearly defined performance standards, thus output measurability is high. In addition, the knowledge of the transformation process is low for the public partner as it lies predominantly with the private partner (Eisenhardt, 1989): almost all activities and the related risks can be shifted to the private partner, meaning that the interaction between the public and the private side can be kept to a minimum. As a result, performance risk becomes more important than relational risk (Das and Teng, 2001). Since both types of risks apply to the two types of PPPs the next section discusses appropriate control mechanisms to mitigate them.

\subsubsection{Choice of control structures in PPPs}


Given the different nature of the activities and the accompanying risks, the PPP literature suggests that PPPs are set up and organized in different ways. This organizational dimension focuses on how tightly or loosely public and private partners are organized (Hodge and Greve, 2007). A tight organization means that the public and the private partners work together intensively during the execution of the project. The PPP might even be established as a separate entity. In other types of PPPs the partners form loose networks of collaboration with a specified time limit, which we refer to as loosely organized PPPs (Hodge and Greve, 2007; Kwak et al., 2009).

DBFMO projects, such as long-term infrastructure projects, are typically loosely organized (Hodge and Greve, 2007). Although the interaction between the public and the private partners is quite intense at the beginning of the project, it becomes less intense once the infrastructure works can start. Before this, the partners need to agree on the basic principles of the project or service that will be contracted out (Klijn et al, 2008). Once the contract is signed, there is limited cooperation and coordination between public and private actors as the private partner is given the right and the responsibility to operate a service to specified levels (Grimsey and Lewis, 2005). This mode of cooperation is a variation of the traditional method of contract allocation (Klijn et al., 2008). The legal relationship of loosely organized PPPs is therefore typically contractual, and the contractual agreements between the partners heavily determine the relationship (Klijn et al., 2008; Van Gestel et al., 2009). Such contractual PPPs usually appear when the public partners have a clear output goal, and therefore leave limited room for the private partner to negotiate. The preconditions for success with this approach to cooperation are that the public party is able to specify the problem (though not the solution, which would be the case in a traditional contractual arrangement) and that clear rules for the tendering process exist (Klijn, 2002). In financial terms, loosely organized projects are often shaped as concessions, especially if the project is fully privately funded (Grimsey and Lewis, 2005; OECD, 2008). In a PPP concession the design, building, financing and commercial operation of an infrastructure project (such as a road or a school building) are integrated into a contract. The added value lies in the lower cost of coordination between the various components and in the opportunity to create substantive added value (e.g. building at a higher quality now and saving on future maintenance cost for the public partner, versus becoming involved in long-term commercially interesting activities with guaranteed demand for the private partner) (Klijn et al., 2008).

DB projects, such as urban regeneration projects, are typically tightly organized (Hodge and Greve, 2007). The reason here is that the various project components need to be intensively coordinated throughout the whole project (Klijn et al, 2008). Urban regeneration projects, for instance, require that conditions are set up for carrying out a wide range of projects and activities with the general aim to regenerate an impoverished urban area. As it is often difficult to clearly delineate in advance the outcome and ambitions of the cooperation (Klijn et al, 2008), the urban regeneration project should be tightly organized to coordinate the activities of the 
(diverse) private and public actors (Hodge and Greve, 2007). Tightly organized PPPs are therefore often governed by a partnership (Klijn et al. 2008). When joint ventures are set up, ownership is shared between the public and private sectors (Grimsey and Lewis, 2005). Typically, all partners are involved in managing the project through the set-up of a special purpose vehicle. Therefore, the legal relationship of tightly organized PPPs is usually participative (Van Gestel et al., 2009). This method of cooperation generates added value by combining substantive activities and projects which then reinforce one another. This also makes it possible to achieve a financial trade-off between profitable and less profitable but socially interesting components (Klijn et al. 2008).

In conclusion, loosely organized projects rely heavily on contractual agreements between the public and private partners, whereby the project goals are set by the public actor. This PPP type implies clearly measurable outputs. At the same time, from the perspective of the public partner, the task programmability is relatively low as the knowledge of the transformation process lies primarily with the private partner. Based on Das \& Teng (2001) and Ouchi (1979), we propose therefore that loosely organized projects will be governed primarily by outcome controls with a tight specification of the outputs in long-term legal contracts. In contrast, tightly organized PPP projects are highly participative in nature. This makes it difficult to clearly delineate in advance the expected outcomes and ambitions of the cooperation (Klijn et al, 2008). Because outputs cannot be defined in a detailed way, we expect that tightly organized projects will be governed less by outcome controls and more by behaviour and social controls (Das and Teng, 2001). Tightly organized projects require close cooperation, which makes the goal-setting process decentralized and evolving in nature. While behaviour controls are suitable to coordinate the tasks between the partners and to facilitate joint-decision-making, social controls are particularly relevant for such ambiguous circumstances (Das and Teng, 2001).This leads us to formulating the following propositions:

P1: Outcome control mechanisms play a dominant role in managing loosely organized public-private partnerships.

P2: Behaviour and social control mechanisms play a dominant role in managing tightly organized public-private partnerships.

\subsection{Socio-political risk in PPPs}

The public sector literature suggests that PPPs possess some typical characteristics that distinguish them from private sector partnerships. The extant literature on management control systems in an IOR context may therefore not sufficiently capture the complexities of PPP governance. To be able to understand the functioning of PPPs, the distinctive characteristics of 
the public sector environment as compared to the private sector need to be recognized as well as the particular risks they create (Abednego and Ogunlana, 2006; Dorado and Vaz, 2003).

First, in contrast to private companies which typically want to earn a return on their investment, public partners are interested in making the best use of public resources and deliver services to the specified standard. In their decision to collaborate with private partners, public partners are not just driven by cost minimization, but also by internal resource capabilities, responsiveness and flexibility, and enhanced learning (Parker and Hartley, 2003). Babiak (2009) describes how community level criteria for PPP effectiveness include overall costs, but also other primary social considerations, such as education, health care, or infrastructure development. As a consequence, the role of public partners in PPPs is not just to monitor the financial viability of the project, but also to assess the environmental impact, guarantee community access and to achieve social policy objectives (Grimsey and Lewis, 2004). Thus, the focus on mainly financial objectives such as profit maximization or cost minimization of the private partners may conflict with the non-financial focus of the public partners. Second, in the public sector political parties take turns in being in power. The arrival of new political parties into power might lead to the discontinuation of concessions and new government policy enforcement (Abednego and Ogunlana, 2006). This influence of alternating political parties might hinder the functioning of PPPs in the long run. Third, the public sector is characterized by particular structures and processes. Since government agencies need to respond to higher mandates, the support received from upper organizations, such as donors or hierarchically superior government agencies is important. Such 'patronage obstacles' related to hierarchically superior agencies can aggrandize or minimize the differences in missions, professional orientations, structures and processes between public and private partners and may further complicate PPP governance (Abednego and Ogunlana, 2006; Babiak, 2009; Dorado and Vaz, 2003; Jennings and Krane, 1994). Previous research has highlighted the need for public administrations to standardize PPP procedures to reduce both the tendering costs to the private sector and the evaluation costs to the public sector, as well as to shorten the negotiation time between both partners (Abdel Aziz, 2007; Grimsey and Lewis, 2004; Kwak et al., 2009). Fourth, the tendency towards turf protection has been recognized as a typical problem in public administrations. Jennings and Krane (1994) refer to turf protection as the notion that each partner has a domain from which it strives to exclude others and minimizes cooperative efforts with those who may be looking to expand in this domain. Turf protection can hinder coordination in projects involving public administrations, particularly when a project threatens the control of functions traditionally assumed by only one of the organizations in the partnership (Dorado and $V a z, 2003)$. Fifth, external pressures from stakeholder groups, such as the influential role of the public at large, cannot be ignored in the public sector environment (Brignall and Modell, 2000). Pressures exerted by the general public may affect the level of conflict and the organizational strategies for dealing with those varied interests. The presence of general public stakeholders 
brings an additional level of complexity to PPP governance (Brignall and Modell, 2000; Dorado and Vaz, 2003).

We therefore propose that the management control framework by Das \& Teng (2001), which has been extensively applied to private sector IORs, is insufficient to fully explain management control structures in different types of PPP projects. We extend the framework by introducing socio-political risks along with performance and relational risks. Figure 1 summarizes the factors creating socio-political risk in a public sector context because of power differentials in public organizations (Dorado and Vaz, 2003). Socio-political risk is clearly distinct from relational risk because it does not cover willingness, and from performance risk because it is not caused by a lack of ability. However, we do not expect these socio-political risks to be totally independent from relational and performance risks, in a similar way that relational and performance risk interact with each other (Das and Teng, 2001).

\subsection{The role of project champions and conveners for governing PPPs}

As the management control literature on IORs is rather weak in dealing with socio-political risk (Dorado and Vaz, 2003; Selsky and Parker, 2005), it may not adequately explain governance structures in complex settings involving many and diverse actors, as in a PPP setting (Westley and Vredenburg, 1997). Instead, governance theory from the public policy literature holds promise to explain governance structures in IORs in PPP settings. This literature stream emphasizes the mutuality in decision making among partners and the accountability among stakeholders (Wettenhall, 2003), and discusses the role of project champions and conveners in the public sector (e.g. Dorado and Vaz, 2003; Dunoon, 2002; Gray 1985; Lawler, 2008; Javindan and Waldman, 2003).

Leadership is identified as the key requirement in making radical changes and modernizing the public sector (Lawler, 2008). This literature does not focus on a conventional and formal type of leadership, but on emergent or informal leaders (Dunoon, 2002). Project champions refer to individuals, involved as a partner in the project, who are able to contribute to the success of the project by using and developing informal systems of relationships (Schön, 1963). Based on a substantial body of research on project champions in the success of intraorganizational projects (Chakrabarti, 1974; Schön, 1983; Howell and Higgins, 1990; Markham, 2000; Markham and Aiman-Smith, 2001), this literature discusses how project champions contribute to public sector success through their fresh insights and vision for the future (Dunoon, 2002; Eglene et al., 2007; Gray, 1985; Lawler, 2008; Javindan and Waldman, 2003). In addition, project champions are sensitive to company politics, they are able to overcome bureaucratic obstacles to keep projects alive, they employ a variety of persuasion techniques, they can leverage resources, and they are willing to take risks for the success of the project (see Markham and Aiman-Smith, 2001 for an overview). Although more than 30 years of research supports the notion that project champions are crucial for the success of projects within 
organizations, the literature on IORs has had little to say about this aspect of leadership (Selsky and Parker, 2005).

The role of conveners is one of third parties, such as researchers, facilitators, and consultants, who try to reconcile partners in order to explore the possibilities of cooperation in the IOR or to provide other support (Selsky and Parker, 2005). Conveners can be invited or uninvited, act formally or informally, operate individually or on behalf of some organization and be advisory or directive in their actions (Lewicky et al., 1992). In contrast to project champions, conveners usually do not have a strong partisan position on the substantive issues in the IOR. Conveners play the role of neutral parties who are act as independent helpers or evaluators (Selsky and Parker, 2005). In the private sector literature, conveners have primarily been studied in conflict resolution settings when third party arbitration is sought (Mohr and Spekman, 1994). In the public sector literature, the role of conveners or third parties has been investigated in the context of public sector labour relations (Lewicky et al., 1992). Empirical research brings about the crucial role played by conveners in developing collaborative cooperation (Gray, 1995; Gray and Wood, 1991; Westley and Vredenburg, 1991). Strong conveners who push partners in an IOR may drive an agenda very significantly and may play an important role in leading the direction of collaborations (Lewicky et al., 1992). Consequently, we expect that both project champions and conveners may play a crucial role in governing the risks in public sector IORs. Since they play a crucial role in responding to the diverse and changing expectations of political and community stakeholders (Mellors 1996, Dunoon 2002), we incorporate them as 'political control mechanisms ${ }^{11}$ in our theoretical framework (Figure 1).We emphasize the role of the political control mechanisms in proposition three:

P3: Project champions and conveners play an important role in managing public-private partnerships (both loosely and tightly organized projects).

\section{Research method}

In this paper, we use in-depth case studies (Yin, 2003) to investigate the public partners' risks and associated management control choices in two PPP cases. The case study method is appropriate because the management control literature on PPPs is still largely underdeveloped (Bloomfield, 2006; Eisenhardt, 1989; Hodge and Greve, 2007). It means that we take a contextual approach, which is useful since the role of management control systems cannot be fully understood in isolation (Otley and Berry, 1994). In addition, since there is little control over

\footnotetext{
${ }^{1}$ The term 'political control' has been used with a more restrained meaning in prior intraorganizational research on management control in local government organizations (Batac and Carassus, 2009; Kloot, 1997). In Batac and Carassus $(2009,111)$, political control refers to the kind of control through fieldwork done by councilors as the basis for controlling the council's actions.
} 
the events, the case study method allows us to take into account the complexity of the interactions and to integrate different sources of evidence (Anderson, 1995; Humphrey and Scapens, 1996; Scapens, 1990; Yin, 2003). Overall, we were able to dig into the details about how and why the PPPs are managed as they are in the cases under study.

The purpose of our study is theory building by gaining analytical generalisation (Eisenhardt, 1989; Ferreira and Merchant, 1992; Yin, 2003). As is the situation in this study, building theory from case study research is most appropriate in the early stages of research on a topic or to provide freshness in perspective to an already researched topic (Eisenhardt, 1989). Based on our literature review we a-priori specified the relevant constructs for guiding the analysis of the cases (Eisenhardt, 1989; Lipe and Salterio, 2000): we have formulated a number of research propositions based on the framework of Das and Teng (2001) for IOR management control and on the project management and public sector literature (Dorado and Vaz, 2003; Selsky and Parker, 2005). At the same time, we tried not to overly rely on our original framework, since 'any apparent coherence achieved by using a predetermined theory as a lens through which to interpret a case could well be gained at the expense of ignoring organisational dynamics and tensions which do not readily fit the chosen theory' (Humphrey and Scapens, 1996, 91).

In terms of its design, this is a multiple-case holistic study (Yin, 2003). The cases cover one unit of analysis, the interfirm relationship, hence the 'holistic design'. Further, the study of multiple cases allows a detailed cross-case comparison. Theoretical sampling informed the selection of the cases (Eisenhardt, 1989): since the types of PPPs are crucial in this study, we made the selection in terms of the organisational relationships (Hodge and Greve, 2007) and hence selected one loosely versus one tightly organised PPP. This also meant that both cases had a different content, i.e. case 1 refers to the construction and operation of a swimming pool, while case 2 is an urban regeneration project, with a different financial and legal structure (Hodge and Greve, 2007; Klijn et al., 2008). In order to maximize the comparability of the two cases, we made sure that the following aspects applied to both cases:

- The selected PPP projects were rated as successful by the major parties involved. In a preliminary interview, the Director of the Knowledge Centre for PPPs in Flanders explained that, in his experience, the most successful PPPs were found at the municipal level. This observation was confirmed by the building group involved. For this reason, the public sector level involved in our study was the local, municipal level.

- Both cases, undertaken by different municipalities, were located in Flanders, Belgium. While the concept of PPP is relatively new in Belgium (Court of Audit of Belgium, 2009; Grimsey and Lewis, 2005), we investigated projects in which experienced private partners participated.

- The projects were similar in size. In both cases, the construction had a modest monetary value (between EUR 5000000 and EUR 15000 000). 
- Both cases related to typical PPP types. Rare and unusual constructions were avoided in order to allow analytical generalizability of the findings (Yin, 2003) in the context of typical PPP arrangements.

- $\quad$ One major building group - referred to from now on as the Building Group - was involved as an important private partner in both cases. However, different public partners and various other private players were involved in each case.

The selection of suitable interviewees was driven by snowball sampling (Goodman, 1961; Salganet and Heckathorn, 2004). The Director of the Knowledge Centre PPP Flanders recommended us to contact the managing director of the Building Group. This managing director became our main contact person and helped us with identifying two successful PPP cases in which his company had been an important private partner. In this way, we were able to get in contact and interview the main key informants of both cases. We gathered about 10 hours of interview material, which we supplemented with a large amount of documents. We managed to get access to minutes of city council meetings, contracts, other legal agreements etc. When building theory from case studies, data analysis frequently overlaps with data collection (Eisenhardt, 1989; Miles and Huberman, 1998). This overlapping and iterative process allowed us to take advantage of flexible data collection. We ended our iterative research approach when theoretical saturation ${ }^{2}$ (Eisenhardt, 1989) was reached, although useful extensions of our study will be discussed in the conclusion of this paper. Table 1 gives an overview of the interview material and documents selected and used for further analysis.

-Insert Table 1 here-

Our interview protocol (Lillis, 1999) contained the preparation of semi-structured interviews. The open-ended questions were based on the theoretical framework depicted in Figure 1. The questions were adjusted during the interview process based on the insights we gained from previous interviews (Eisenhardt, 1989; Humphrey and Scapens, 1996). All interviews were taperecorded and fully transcribed for further analysis. We started analysing the rough data using a coding scheme based on our literature review (Saunders et al., 2006). At the same time, we were looking for new insights and therefore stayed open for unexpected elements to come in during the data collection process (Silverman, 2005). These new elements were added as free nodes to our coding scheme. The next step in our analysis process consisted of structuring the data in thematic conceptual matrices (Miles and Huberman, 1998). Summaries of these thematic matrices are presented in the Analysis section of the paper. After a detailed withincase analysis of each of the cases, a cross-case analysis took place (Miles and Huberman, 1998).

\footnotetext{
${ }^{2}$ Theoretical saturation means that the study can end when the incremental improvement of the iteration process towards theory is minimal (Eisenhardt, 1989).
} 
We paid careful attention to assure the quality of our research approach by focusing on issues of reliability and validity. Reliability refers to the extent to which evidence is independent of a person using it, in other words to the consistency of the research process and to its reasonable stability over time and across researchers and methods (Yin, 2003; Ryan et al., 2002). Validity refers to the extent to which the data are in some sense a 'true' reflection of the real world, in other words to the way in which field researchers manage to analyze their data in order to reach credible results (Silverman, 2005; Eisenhardt, 1989). To ensure validity, we followed several techniques to avoid premature and false conclusion drawing due to information processing biases (Eisenhardt, 1989), like cross-validating the interview transcripts and the documents. The systematic coding process based on the coding scheme aimed at making sure that the analysis was based on all the relevant evidence, and that all major rival interpretations were included (Yin, 2003). We further tried to maximize the validity of our study by coping with potential researcher bias: two of the researchers were involved in independently coding the data. When their opinions about the coding differed, they discussed the differences in order to reach a consensus. In addition, we discussed our observations and findings with the interviewees and incorporated their feedback in the analysis of the data. The interview and analysis protocols, including our coding scheme, were important for maximising the reliability of our study.

\section{Analysis of the cases}

In this section we introduce both cases, first the long-term infrastructure project (case 1), followed by the urban regeneration project (case 2). Table 2 provides an overview of the two cases. For each case, we describe the content of the PPP and parties involved (cf. Panel A of Table 2), the task and public sector characteristics of the PPP and the resulting risks (cf. Panel B), and finally the PPP organization and management control mechanisms used (cf. Panel C).

- Insert Table 2 here -

\subsection{Case 1: a long-term infrastructure project}

\subsubsection{Content of the PPP and parties involved: case 1}

The infrastructure project of case 1 involved the construction and operation of a municipal swimming pool, whereby complementary sports and recreational facilities (i.e. fitness and sauna) were offered.

'The municipality finds it a plus that these additional facilities can be offered, but we do not consider this as our public task'. (Mayor, Case 1)

This PPP was a typical 'Design Build Finance Maintain Operate' (DBFMO) project, in which the private sector was responsible for the design, construction, financing, operation, and maintenance of the project for a specified time, while the public sector retained ownership of the project (OECD, 2008; Kwak et al, 2009). From the public partners' side, two adjacent 
municipalities joined forces to fulfil their public task of offering appropriate school swimming facilities. Recent changes in regulations and environmental prescriptions forced the municipalities to dismantle their existing swimming pools. In addition, the old pool of the largest municipality had been damaged by a fire at that time. Both municipalities formalized their cooperation by setting up an 'Interlocal Association' (see Statutes, Interlocal Assocation).

'We set up a new form of inter-municipal cooperation - the most simple one - an Interlocal Assocation. This initiative was largely supported by all political parties in both municipalities.' (City Secretary, Case 1)

'We try to encourage such a cooperation between different municipalities, in order to broaden the basis of the project' (Managing Director, Building Group).

The private parties were selected through a public tender. The municipalities formed various working groups that independently judged the proposals by the private partners in terms of their financial-legal aspects, their vision on sports, and their urban development point of view. A consortium with the Building Group came out as the best candidate in terms of each of the selection criteria. The Building Group constructed the swimming pool and afterwards became involved in a consortium with two other private parties for maintaining and exploiting the pool. The aim of this consortium was to run a profitable sports complex, including a swimming pool but also offering a wide range of other sport and recreation facilities (as outlined in the Business plan of the private consortium). This freed the public partners from the daily tasks of monitoring the construction and all operational activities.

'Our policy objectives are in the first place directed to our senior citizens... which means that we have to deal in a different way with providing the swimming facilities for schools... The technical department of our municipality had more than enough other projects to execute and follow up'. (Mayor, Case 1)

'We only wanted to offer school swimming, but we did not want to get involved in maintaining the facilities, setting the prices etc...' (City Secretary, Case 1).

The public partner wanted to outsource the execution of the project, but at the same time remain owner of the construction grounds. The public partner insisted to set up the PPP as a territory concession in which the private partners were asked to execute the project, while the public parties would simply pay for a successful execution (as detailed in the Territory Concession Agreement between the public partner and the private consortium). The remuneration to the private party would include a sum for the school swimming offered, as well as a limited repartition of the profits. The municipalities were willing to guarantee a municipal deposit for the loan the private consortium had to take. Since municipalities have a better credit rating than private companies, this resulted in a better interest rate and a better tax regime. At the same time, the territory concession meant that the municipality would be able to claim back the territory at any time. Therefore it took some time to convince the private partner to gain confidence in the arrangement proposed by the municipalities. 


\subsubsection{PPP characteristics and risks involved: case 1}

The swimming pool project was straightforward in terms of its output requirements. Both municipalities came together to figure out the capacity requirements with respect to the school children and the other citizens. In other words, output measurability was high. The transformation process was less clear for the public partner, who therefore relied on an experienced private partner with considerable knowledge of the construction process. The private partner was thus expected to be able to adjust the project during the construction process when it was offered sufficient freedom to organize and execute the project according to its knowledge.

'In addition, we were convinced that if we found a partner that would be responsible for the construction AND exploitation of the swimming pool, this partner would be adjusting the project during the construction process'. (Mayor, Case 1)

The public partner was mainly concerned with performance risk in the project. Providing swimming facilities to schools is a service imposed by the federal government. The municipalities wanted to outsource the swimming service as they regarded constructing and maintaining swimming facilities not as their core business. In addition, they wanted to pay a fixed price for this service which was lower than their current cost of operating the swimming pools. At the same time, they retained the ultimate responsibility of providing this service at high performance standards with respect to quality, safety, hygiene and service within their municipalities. The public partner had therefore gone to great lengths to find a suitable partner that could execute the service at the required standards. However, at that moment few private partners had experience with offering swimming services for schools as all municipalities in Belgium were organizing this service themselves. The public partners even visited foreign municipalities to learn from their experience in outsourcing this service to a private partner. Their main concern remained whether the private partner would have the capabilities of offering the required service at the price they were willing to pay.

'Together with the previous and the current mayor, I traveled several times to the Netherlands to visit 3 or 4 swimming pools. The first thing we noticed was that 90 percent of the municipal swimming pools were a PPP in which the private partner took care of the operating the swimming pool. And what we saw there was also important: there were people swimming, but also people in the gym, and in the sauna, etc. This is obviously commercially attractive. It is not just a swimming pool, but also eating together in the cafeteria, spinning in the gym and so on. It was really a family event. We learned a lot.' (City Secretary, Case 1).

As the public partner wanted to focus solely on the outcomes of the project, they decided not to interfere with the execution of the project. Thus, relational risk was assessed to be relatively low, as illustrated by the following quote:

'These cities go very far in transferring risks to the private partners: they draw the framework, and then leave the execution completely to the private consortium. I think 
this is optimal when there are joint goals: a well managed swimming pool, a good ticket sale, happy customers... this is a win-win situation for both parties'. (Managing Director, Building Group).

The public sector environment of Case 1 also led to a number of socio-political risks.

One such risk related to the important differences in the desired outcomes sought by the public and private partners. The public partner wanted to outsource a non-core service so that they could focus on other projects. Although they wanted the fee that they had to pay to be lower than the current cost of offering the service, their most important concern related to the performance standards of the service. In contrast, the private partner wanted to run a profitable sport complex. Offering swimming facilities to local schools was not their main objective and they wanted to ensure that the compensation for this service was sufficient. At one crucial moment the diverging goals between the public and the private sector became a serious issue. When, after a long negotiation period, the contract was finally designed, a special city council meeting was organized so that the cooperation agreement between the public and private partners could be signed. Exactly during this meeting, one of the private companies involved in the consortium wanted to negotiate a financially better position. The mayor of the major municipality reacted firmly and expelled this private party from the PPP agreement. At the same time, he gave the two remaining private parties the chance to stay in or to leave the project altogether. Both accepted to continue on the terms agreed on during the preceding negotiation.

Alternating political parties also often constitute an important source of socio-political risks. The specific culture of the municipality was indeed indicated as an important risk determinant, even if it did immediately affect this specific project:

'In some cities, the composition of the city council is more stable than in others. This can increase the reliability of its governance, for example, when a certain political party is governing for years - although we know this can change all of a sudden' (Managing Director, Building Group).

Because two different municipalities were involved, we expected that this could increase perceived socio-political risk. However, various interviewees explained that this complexity was taken into account by introducing clear repartition keys between the municipalities. There was an open communication with both city councils and this complexity did not seem to affect the risk.

'There was a need to create a win-win feeling for both municipalities: one has a location advantage (the swimming pool was built in its territory) and therefore pays $60 \%$ of the deal, the other municipality pays the other $40 \%$ ' (Mayor, Case 1 ).

On the other hand, socio-political risks in this PPP increased due to the support needed from federal tax agencies to obtain a tax ruling. As the project was set up as a territory concession, it needed support from the hierarchically superior government agency. This induced substantial uncertainties in the long-term infrastructure project, which needed to be cleared out before the 
contract between the private and public partner could be signed. The partners were thus confronted with tax uncertainties delaying the contract phase.

Turf protection was another significant issue in this long-term infrastructure project. The municipalities did not want to involve the alderman and officials responsible for sports in the PPP, since they wanted to completely outsource the construction and management of the swimming pool. It turned out to be difficult to convince these individuals to let go of their former tasks and outsource these responsibilities to the private sector.

'We needed to convince these people that they were not going to be involved in the construction nor exploitation of the pool. Instead of managing the facilities, the task of these people becomes more directed towards motivating our citizens to go to swim. But to some of them it seemed to come across as if we were depriving them from their job. This meant a radical change for some of our municipal employees, and it required a total change in mentality' (Mayor, Case 1).

External pressures from stakeholder groups played an important role as well. To involve the general public, information meetings were held and electronic newsletters were sent out. Initially, the territory concession led to heavy protest against the project, but once the press started to react positively, the protest turned into approval.

'In the beginning there were problems with sport clubs like the diving club who wanted to interfere. We have said no, sport clubs should not have a say in how the operation of the swimming pool should be performed. For those clubs this was not obvious...' (Mayor, Case 1).

'We also used to have an outdoor swimming pool where people came from far and wide. Many said it was sad to close it. There were so many aspects to take into account and the communication therefore needed to be highly transparent' (Mayor, Case 1). 'In the other municipality it has prompted some discussion, especially because the proposal was to build a swimming pool in our territory, not in theirs. They needed more persuasion to convince everyone' (City Secretary, Case 1).

\subsubsection{PPP organization and management control mechanisms used: case 1}

The nature of the activities and the risks involved led to a loose organizational relationship between the public and private partners: the Interlocal Association delegated the tasks of operating the swimming pool to the private consortium. This freed the public partners from the daily tasks of monitoring the construction and all operational activities.

Since the public partner did not want to be involved in operating the swimming pool on a day-to-day basis, they were mainly concerned with setting up appropriate outcome controls to follow up whether the required services were provided by the private partner. As described above, the output measurability in this project was high: building and maintaining a swimming pool set a clear mandate to the private party (as outlined in the Execution agreement between the public partners and the private consortium). The municipalities set up a simple text with their 
requirements in terms of the swimming facilities they wanted to offer. Once approved by the city council, they actively searched for a private partner along these requirements. They reached a cooperation agreement with a group of private partners, but they took quite a long time to thoroughly negotiate on the terms of the contract. The mayors, city secretaries, sports officials and lawyers specialized in public services were closely involved.

'We spent a lot of time at the initiation of the project - to write up the mutual rights and obligations. These were incorporated explicitly and in detail in the contract' (Mayor, Case 1).

'We had meetings during one and a half years with all parties in order to reach a cooperation agreement. We have spent a lot of time in this phase, since this had to be a good solution for the next 30 years' (City Secretary, Case 1).

'In this project, quite some time had been spent before finalizing the contract. At that time, there were not that many examples of PPPs. Quite some time was needed to get everyone at the same wavelength' (Managing Director, Building Group).

Since the Interlocal Association delegated the swimming pool project to the private consortium, behaviour controls were less relevant. There were yearly meetings of the Interlocal Association with the private consortium, but their main objective to discuss the yearly follow-up report to see whether all required standards were met. In addition, when technical problems occurred, the private partner had been quick to solve them - since this was in its own interest.

'Since the private partner becomes the owner of the pool for 30 years, he will not do anything harmful because he would immediately feel the consequences. So there is no need for further control' (Managing Director, Building Group).

In terms of the social controls, the city council meeting at which the cooperation agreement between the public and private partners was to be signed, created a trust crisis from the side of the municipalities as one of the private companies tried to extract some extra rent from the negotiations. The municipalities decided to expel this private party and continued to work with the two remaining, trusted private parties.

'We had chosen this consortium because one of the partners already had experience with operation of swimming pools in the Netherlands. But, at some point, when we were ready to sign a final text of the cooperation at our council and at which they were invited to express their views, this private partner with experience thought they could grab some more. ... I then suspended the meeting with them. To the other parties, I asked if they wanted to continue the operation.' (Mayor, Case 1).

After the contract was signed, interactions between the public and private partners was limited to annual meetings to check whether the required outcome levels with respect to service, quality and service were met. Outcome control thus played a major role, while behavioural and social controls had a limited role.

The data revealed the important role of project champions and conveners in this case. We observed that the long-term infrastructure project would not have survived the confidence crisis 
without the interference of the mayor of the largest municipality. During the interviews and in the document analysis we learned that he was an important project champion in Case 1. He was generally recognized for his strong leadership qualities and his competence because of his legal background and extensive experience with concession projects in another domain. He appeared to have a clear vision about the direction in which the swimming pool project had to go, already since he was an alderman at the initiation of the project.

'The major had an important influence on the project. For instance, his experience in the port played a major role in the design of the project. At that time he was not even a mayor, but a member of the council. The private partner was sceptical. But our counsel too; even I was not convinced of the proposed construction. But somehow he could convince all of us that a concession was the most flexible contract for the project. Later on this was confirmed after I investigated the tax consequences. The concession construction would allow us to recover more of the VAT' (City Secretary, Case 1).

The crucial role of project champions was also stressed by the private partner:

'When problems happen, it is important to solve them. In this context, it is important to have strong personalities that can take the others in tow. I have seen examples where this was not the case, and where, after certain problems, the whole project collapsed' (Managing Director, Building Group).

From the side of the private party, our main contact person at the Building Group showed the characteristics of a project champion. He had a clear vision about how a PPP should function and promoted team spirit to bring PPPs to a successful end.

'Due to the increase in complexity in terms of techniques and processes, cooperating under a hierarchical structure does not work anymore. .....Instead... we now have to cooperate as a team.... too often, people meet only once. Instead, we need to work together as a cluster of interested parties'.

In his presentations about the role of PPPs, he was clear about the values he found important:

'Communication needs to be clear and direct, involving all participants... Culture, care, respect, equality, a joint vision are crucial for a successful PPP project' (Powerpoint slides, Building Company).

In addition, several conveners stood out as having played a major role in this PPP project. In the first place, the municipalities of both projects contacted the Knowledge Centre PPP Flanders, searching for know-how and expertise in terms of PPPs at the local level (see Output specifications, brochure Knowlegde Centre PPP Flanders). In addition in Case 1, specialized lawyers played an important role to convince all parties of the contract structure proposed.

'During the negotiations about the format of the PPP, some people needed to be convinced that the territory concession was a suitable formula. We involved a lawyer group specialized in public services. We did not involve a local lawyer... in terms of the vision about the legal formula, several parties have long stood against each other. It 
was the external party, these specialized lawyers, that helped us out. Otherwise we would not have managed to get to a result today' (Mayor, Case 1).

\subsection{Case 2: an urban regeneration project}

\subsubsection{Content of the PPP and parties involved: case 2}

The urban regeneration PPP in case 2 aimed at reviving a once flourishing city centre (as outlined in the Final Cooperation Agreement, City Development Company and Building Group). The municipality which initiated this PPP (located in a different region in Flanders than the swimming pool project in case 1) had established a City Development Company as the responsible public partner in this project. The City Development Company used a public tender procedure to select a private partner - the Building Group - to cooperate in the development of an initially large downtown area. The Building Group became involved in the regeneration and construction parts of the project. While the development process was expected to break-even, the construction part of the project was financially interesting for the Building Group. Since it was their first project in the region, the Managing director of the Building Group also wanted his company to get known in the region as a solid partner in a PPP context. The public and the private partners set up a separate special-purpose company to host their city development initiatives (as detailed in the Establishment Act of the special purpose PPP Company). The City Development Centre bought land in the target area and attributed a building lease to the special purpose PPP Company. The Project Department of the Building Group acted as a shareholder in the special purpose company, while the mother company of the Building Group was the contractor for the housing- and shop facilities (see Building Contract, special purpose PPP Company and Building Group).

'The structure with a separate special purpose company was a try-out: we wanted to get access to the knowledge of our private partner, and at the same time find a way to have an open-bookkeeping system' (Director, City Development Company, Case 2).

\subsubsection{PPP characteristics and risks involved: case 2}

The output measurability of the urban regeneration project was initially low, therefore the private partner was selected in terms of general criteria, not in terms of the construction details or the financial result:

'When setting up the project and selecting the partner, we did not monitor the financial viability of the project, but we assessed the vision and strategy of the potential partner to achieve our social policy objectives, which was the improvement of the area.' (Director, City Development Company, Case 2).

During the process, the output objectives slowly became sharper and the PPP started to include projects to offer attractable shop keeping facilities and housing in this impoverished downtown area. The city especially wanted to provide comfortable apartments to attract families with children to this part of the city centre. 
Following the low degree of output measurability, the knowledge of the transformation process was initially also low in case 2 . Since the development part was an inherent aspect of this PPP, it entailed a creative process involving all parties. This intensive cooperation between the partners led to a high degree of relational risk. The public partner expressed that they even felt uncertain about the way in which they needed to organize this crucial stage of their urban regeneration process:

'...we were not sure about the right formula: how to find a partner, how to execute this project, to work with a partner taking risks or with a building lease?' (Director, City Development Company, Case 2).

Performance risk in case 2 was high. The public partner experienced this PPP as a difficult project, first because they could only be certain about the successful regeneration of the downtown area once the whole project was finished. Second, the land and construction costs were heavy if weighted against the uncertain potential benefit.

'Through our informal contacts with the market, we knew that this regeneration project would probably not be profitable' (Director, City Development Company, Case 2).

But also the private partner expressed that:

'It is a very uncertain project: what will the future bring for this city? In the meantime, a lot of other aspects - architecture, destination of houses, buildings around the project change and evolve... things we do not have under control' (Managing Director, Building Group).

Since the profitability of the project was uncertain, the public and private partners decided to each take an equal stake (of almost $50 \%$ each) in the special purpose PPP Company. The feasibility study undertaken when starting up the PPP had included a limited risk analysis. This formed the basis for the Building Group to determine its construction fee. However, the public party did not undertake an elaborate risk analysis, even not in terms of whether they would be able to sell all the apartments. The Building Group and the City Development Company were both prepared to buy several apartments themselves in case the project turned out not to be successful. At a given point in time, however, a real estate developer stepped jn and managed to take over the most interesting part of the construction project, which increased the performance risk even more for the private partner and introduced a high financial risk. Nevertheless, when the project was finished, the interviewees from the City Development Group confirmed that they considered the project to be successful in terms of the boost given to the downtown area and the efficiency of the whole regeneration process. With some profit made, the project would have been a real success story. The success of this initial PPP project for the city led to the initiation of new PPPs in which the Building Group was sometimes involved. In addition, the private partner managed to realise the reputation of being a solid partner for PPPs.

The socio-political risk related to case 2 was high and induced by various issues. In the first place, the contrasting goals between the public and the private party were more dominantly present in case 2 than in case 1 . While the PPP project initially covered a wide area of the city, 
this changed during the process as a large real estate developer was able to convince the City Development Company to obtain the sole right for developing a financially interesting part of the renewal area. The City Development Company agreed, after having obtained a damage compensation for the breach of contract towards other parties, such as the Building Group involved. This event highlights the divergent goals of the public party: while the Building Group was primarily interested in the return on investment of the project, the public partner was primarily concerned with important non-financial objectives such as the general improvement of the area, and they even let down their partner in the special purpose company to reach this goal. Second, in case 2, just like in case 1, the socio-political risks in PPPs increased due to specific public legislation and procedures imposed by hierarchically superior government agencies. These rules complicated and influenced the governance structure in the urban regeneration project. The partners adapted their governance structure by limiting their financial stake to $49 \%$ in the special purpose PPP Company (as outlined in the Final Cooperation Agreement, City Development Company and Building Group; Shareholders' agreement for the PPP Limited Company) in order to avoid becoming a majority shareholder, so that the project would not fall under the restrictive public tendering legislation. A minority shareholder was therefore deliberately involved as an independent party in the special purpose PPP Company. This minority shareholder held the remaining $2 \%$ of the shares, did not have voting rights, but was appointed for his advising role (as detailed in the Shareholders Agreement of the special purpose PPP Company).

Another important socio-political risk is the potential pressure from external stakeholder groups. In case 2, the Building Group felt the fear of the municipality towards potential opportunistic behaviour by real estate developing companies and contractors, especially because the public partner retains the liability to ensure the performance of any duty imposed upon the municipality. Transparency of costs and benefits are crucial to solve this issue. This was exactly one of the reasons why the special purpose company was set up and an openbookkeeping system was installed. Another issue was the target public, the citizens. Since the building plans would temporarily cause a lot of inconvenience for the private properties, its successful implementation would depend to a great extent on the goodwill of the neighbourhood. The neighbours were well informed about the downtown regeneration plans and the reaction was very positive. So in contrast to what the literature often suggests, this PPP project even led to a number of supporting private initiatives:

'Our initiatives worked as a lever in the neighbourhood: because they knew that we were going to renovate some impoverished buildings, several small private owners started to take their own renovation decisions' (Architect, City Development Company, Case 2).

\subsubsection{PPP organization and management control mechanisms used: case 2}


Both public and private partners - operating through the special purpose PPP Company - were intensively and jointly involved in the design, financing, construction, sale and/or exploitation of the projects of case 2. We described above how the City Development Company and the Building Group set up this separate company to host their city development initiatives. It is therefore clear that the nature of the activities and the risks involved in the urban regeneration project led to a tight organizational relationship between the public and private partners.

In contrast to Case 1, output controls were relatively less important than behaviour controls in Case 2. The contract for the urban regeneration PPP was based on the feasibility study and formed the basis of the cooperation agreement. However, the different parties quickly went from the formal agreements towards the urban development process, during which the contract was not further consulted.

'After downsizing the original regeneration project, we decided not to change the contracts, the statutes and the aim of our special purpose company, but just to continue with the real work. Nor we, nor the Building Company asked for explicitly incorporating all changes in the contracts. Instead, these changes were clearly reported in the minutes of the board of our special purpose company' (Director, City Development Company, Case 2).

Behaviour and social control took place in the form of regular meetings of the City Development Company and the Building Group. There were weekly yard meetings, meetings of the executive committee (consisting of the Director and architect of the City Development Centre and representatives of the Building Group) and meetings by the Board of Directors. These formal meetings were an important means to follow up the progress of the project, but at the same time they were important instruments for social control, as they made sure the private and public partners increasingly knew each other.

'This downtown development project was a participative PPP that requires a continuous interference by the city: they need to stay involved in the development' (Managing Director, Building Group).

'We usually went to the Board with our solutions, not with the problems, as these were discussed during the works. The coordination took place at the yard, in an amiable atmosphere' (Architect, City Development Company, Case 2).

We noticed that the Building Group acted as the contractor of the shop- and housing facilities. Their invoices were sent to the office of the City Development Centre, where they were checked before being paid. This meant that de facto, open bookkeeping was also used as an important behaviour control instrument.

In terms of the social controls, it was clear that a careful selection process had been essential for the public party before they wanted to step in the PPP with the private partner. Since the project outcomes were unknown at the start of the project and the different parties worked closely together in a joint-decision making process, it was impossible to foresee every 
possible event, hence trust became crucial. The Building Group had been selected based on a concise proposal:

We selected the private partner because of their clear vision on the regeneration of our city, their architectural vision, and their prior experience with PPP. A financial plan was not required' (Director, City Development Company, Case 2).

Furthermore, trust between the public and private partners seemed to grow during the process. Another important social control aspect for a successful PPP, as indicated by the private partner, is the culture of a city:

'The main problem is that PPPs involve a long-term contract, but with a short-term partner. There is a lot of uncertainty about who is going to sit at the other side of the table in five years time... So flexibility, trust and stability of the partner are crucial' (Managing Director, Building Group).

When the real estate developer managed to take over the financially most interesting part of the initial project, the PPP was at risk. This crisis brought the Building Group in a difficult situation:

'For our Building Group, a lot changed when the real estate developer took over part of the project. The original project was significantly reduced... We have participated in the development, but in the end we are only constructing a small part of the total project... and that was expected to lead to a loss.... But we wanted to go on, because we hoped that other, more profitable projects would follow in the future in that region that was new to us... We look at the long-term effect of our participation in this project: with this experience, we will be a suitable candidate for future projects with this city and in the neighbourhood' (Managing Director, Building Group).

'They realized they needed to weather the storm ... And indeed, their activities in our city have led to other PPP projects in the region' (Architect, City Development Company, Case 2).

It was because the managing director of the Building Group believed that even an unprofitable project now could be beneficial for the Building Group in the future, that he was able to convince his company to go on with the project. The director of the Building Group stood up as a strong project champion in this most critical moment. He was able to convince his private sector colleagues about the potential merits of continuing the PPP.

'Our cooperation has fortunately survived this drastic change. This has further increased the trust we had in each other' (Architect, City Development Company, Case 2).

Besides the managing director, the mayor also turned into a project champion. Although the City Council was not directly involved in the PPP in Case 2, the mayor was closely involved because he acted as the chair of the City Development Company. Because of his legal background, people experienced him as a competent partner. 
'Our mayor, himself a lawyer, did quickly steer this cooperation towards an independent structure. He was supported by the Managing Director of the Building Group' (Architect, City Development Company, Case 2).

'I think that characters like $\mathrm{Mr} \mathrm{X}$, our mayor, have played a crucial role in the success of this PPP. If he aimed at a certain level of quality, or if he said something, this was generally accepted by all parties'. (Director, City Development Company, Case 2).

Also in case 2, conveners had a significant influence. One small shareholder was deliberately involved as an independent party in the special purpose PPP company. This party held $2 \%$ of the share, while the City Development Company and the Building Group each held $49 \%$ of the shares. This minority shareholder did not have voting rights, but was appointed for his advising role. In addition, the special purpose PPP Company engaged an independent coordinator to follow up the project into detail. The coordinator had a number of engineers with experience in similar building projects. They monitored the agreements, including the costs, were responsible for the budgetary controls, etc. It made the City Development Company confident that the contractor was going to solve certain issues in a cheap way. However, this independent intermediary has not had to interfere often.

'This independent party played an important role for this PPP, especially because of the special structure. The Project department of the Building Group is our partner in the Special Purpose company, while the mother company of the Building Group is the constructor. This neutral party made sure we of the City Development Company got the necessary trust in this construction' (Director, City Development Company, Case 2).

Further, a number of local real estate agents had been involved early on in the project: they gave advice in terms of the degree of completion required for bringing the apartments on the market.

'They gave a voice to the potential buyers' (Architect, City Development Company, Case 2).

Finally, an independent architectural firm was involved in drawing the plans that the Building Group as the contractor of the construction phase had to execute.

\section{Discussion and conclusion}

This paper investigates the role of management control for the governance of public-private partnerships (PPP). Our analysis draws on data gathered from a comparative case study analysis involving two cases at the municipal level, namely a long-term infrastructure project and an urban regeneration project. More specifically, we study which management control instruments are relevant for managing these two distinct types of PPP arrangements. We describe the characteristics of these public-private IORs, the risks involved, the organizational structure of the PPP and the management control mechanisms adopted by the partners to minimize the different risks. Despite the growing practical significance of PPPs, there is a paucity of academic research into management control of IORs involving public-private 
cooperation. This paper contributes to enhancing our understanding of these relationships by extending the IOR management control framework of Das and Teng (2001) with risk and control concepts from the public sector literature. Two important conclusions from our comparative case study are that (1) the Das and Teng (2001) framework with its focus on performance risk and relational risk is insufficient to describe the socio-political risks in PPPs, and (2) that in order to manage the particularly high risk situation of PPPs, the success of these forms of IORs depends on political controls that are not typically examined in private IOR frameworks. We will discuss each of these findings in more detail.

First, our analysis of the two cases provides clear evidence that, besides relational and performance risks, both PPP cases also face important socio-political risk. This socio-political risk derives from political obstacles caused by the need of the public partners to respond to other parties such as the community they serve, turf protection, the cooperation with and between political parties, and hierarchically superior government agencies. We find in both cases that socio-political risk was clearly distinct from relational risk because it did not depend on the willingness of the partners involved, and from performance risk because it was not related to a fear of lack of ability. However, we observed that socio-political risk was not independent from the other types of risk, but that it rather reinforced the relational and performance risk. For example in the long-term infrastructure project (case 1) socio-political risks caused by turf protection of the alderman and officials responsible for sports within the public organization at first aggravated relational risk. The conflicts that were raised from their interference with the private partner's operations of the swimming pool at first augmented the tension between the public and the private side. It was only after an intervention of the mayor towards the sports officials and the alderman that the tensions between the public and private partner disappeared. Similarly, as the socio-political risk increased due to the uncertainty whether the public partner would receive support from the hierarchically superior government agency with respect to the tax ruling, the performance risk of the project was at first perceived to be extremely high, resulting in very fierce and long contract negotiations. In case 2 , the urban regeneration project, we noticed similar interactions between the different risks. Especially the socio-political risk induced by the community level goal of the public partner increased the relational and performance risks. The public partner was mainly concerned with the nonfinancial objective of improving the area, while the private partner was primarily interested in the return on investment of the project. Because the public partner believed it would serve their goal of regenerating the area, they decided to accept the project proposed by a large real estate developer while the PPP with the Building Group was already running. This breach of contract towards the private partner highlights the socio-political risk due to the divergent goals of the public party. Since the newcomer was able to take over the financially most interesting part of the contract, the reduced project lost any prospect of profitability. At the same time, the relation was at high risk because the private partner's trust was violated and the willingness to cooperate could have been totally eliminated. 
Second, in line with the framework of Das and Teng (2001), we conceptualized IOR control structures as combinations of outcome, behaviour and social control mechanisms. However, given the influence of the three types of risk discussed above, we propose that the management control framework by Das \& Teng (2001) is insufficient to fully explain management control structures of PPPs. The public sector literature points at the role of project champions and conveners to reduce socio-political risks in public settings. We therefore introduce project champions and conveners in our management control framework as political control mechanisms, in that they are expected to be able to respond to the diverse and changing expectations of political and community stakeholders. The results of our study show that typical IOR control expectations from the Das and Teng (2001) framework hold for the two types of PPP arrangements studied. In the long-term infrastructure project, the public sector partner was able to clearly specify the problem and output requirements upfront. As the project was fully outsourced to the private partner, very little interaction between the partners was required during the execution of the project. As a consequence, the performance risk was more prevalent than relational risk and the parties decided to loosely organize the PPP. The case results provide strong support for our first proposition, stating that outcome-based control mechanisms play a dominant role in managing such loosely organized PPPs. Since the project goals were clearly spelled out from the start of the project, the partners could heavily rely on contractual agreements. In the urban regeneration project, it was more difficult to clearly delineate in advance the expected outcomes of the development process. The scope of activities was expected to evolve during the execution of the project, and the intensive cooperation needed between all partners led to a PPP that was highly participative in nature. The partners decided therefore to set up a tightly organized PPP in which the public and private partner worked closely together. We expected, in our second proposition, that behaviour and social control mechanisms play a dominant role in managing such tightly organized PPPs. Again, this proposition was supported by our results. In line with our extension of the Das and Teng (2001) framework, we formulated our third proposition that project champions and conveners play an important role in governing PPPs, which was also supported by the data. In case 1 , the mayor of the major municipality figured as a crucial project champion. In case 2 we observed how, besides the mayor, a representative of the private party (in our study the Managing Director of the Building Group) actually became the most enthusiastic project champion, explicitly recognized by the public parties. Conveners, acting as neutral third parties, brought in a second type of political control. In both cases, the municipalities felt more comfortable when specialized lawyers were involved as conveners. The search for a neutral party was also reflected when the public parties in both cases contacted the Knowledge Center PPP Flanders, a governmental agency aiming to encourage successful PPPs. The public party in Case 2 also called in a number of smaller conveners, like an independent coordinator at the yard, local real estate agents, and an independent architect. 
Even more interesting is that we noticed in both cases how the political control mechanisms, apart from their contribution to manage socio-political risk, also impacted the other types of risks and controls. In case 1, the mayor's firm way of acting against the turf protection and the unexpectedly rent-seeking private partner did not only curb socio-political risk, but also reduced relational risk between the public and the private partners. In this way, his behaviour even increased the social control mechanisms, because afterwards mutual trust increased. A similar role was observed with the lawyers, called in to reduce socio-political risks threatening because of the unfamiliar territory concession formula and the resulting tax uncertainties caused by the governmental hierarchy in which the municipalities operate. These lawyers did not only contribute to managing the socio-political risks, but also to reducing performance risk: the fact that the territory concession as the most feasible set-up of the PPP could be established made the whole project more profitable. In case two, the contract breach by the public partner made the future of the PPP highly vulnerable. Without the long-term vision and courage of the Managing Director of the Building Group, the PPP would not have been continued. Again, this political control mechanism did not only counter socio-political risk, but also contributed to a growing trust between the private and the public side. Another remarkable issue is that the increasing maturity of the output requirements throughout the process of the urban regeneration project would have allowed the PPP partners to start installing additional output controls. However, given the trust level gained at that stage, the partners did not feel the need to change the original contract and the other outcome and behaviour control mechanisms.

We acknowledge a number of limitations to this study. The findings are based on two PPP case studies, a long-term infrastructure project and an urban renewal project, at the municipality level in Flanders, which limits the direct generalization to other settings. Although we deliberately sampled successful partnerships, no assessment was made of the performance consequences of the PPPs studied and, in particular, of the control systems by which they are governed. Therefore, it should be noted that the described management control structures are not necessarily optimal ones and that they are not necessarily applicable to other settings. We would consequently like to provide the following suggestions for future research. First, by focusing on two typical types of PPP arrangements, a long-term infrastructure project and an urban regeneration project, we were able to select two cases for which we expected ex ante to observe different control risks and management control structures based on the Das and Teng (2001) framework. These expectations were confirmed by our empirical data. However, the PPP concept also seems to encompass other families of arrangements (Hodge and Greve, 2007). Examples are PPPs for institutional cooperation for joint production and risk sharing, PPPs for providing public services and developing civil society in post-communist regimes, as well as a mechanism for combating social exclusion and enhancing community development under European Union policy. It is clear that these PPP families cover a wide array of governance types and that future research is needed to analyze whether our findings and conclusions also apply to these types of PPP arrangements. 
Second, like prior intra-organizational management control research in the public sector (Batac and Carassus, 2009; Kloot, 1997), our research focuses on local public organizations (i.e. municipalities). We selected PPP cases at the local municipal level in order to be able to analyze control choices from initiation, over follow-up and closing of the project. Since the concept of PPP is relatively new in Belgium, no federal PPP projects had been fully completed when we started this study (Court of Audit of Belgium, 2009; Grimsey \& Lewis, 2005).

Additionally, our focus on PPPs at the municipal level allowed us to select cases that were similar in size, i.e. monetary value. However, the specific features of these local municipalities have potentially a major influence on the way relationships with private partners are managed. Several of our contact persons, especially the Managing Director at the Building Group, stressed that PPP initiatives create interesting dynamics at the local level, where the size of the project is in accordance with the size of the municipality and the number of parties involved is limited and a number of enthusiastic players can take the lead. For larger projects a higher (federal) public sector levels, the number of public and private parties involved might increase significantly. This could make the PPPs a lot more bureaucratic and rigid. This could imply that the role of project champions and conveners as identified in our local PPP cases could be different at higher (federal) public sector level. One fruitful avenue for future research might be to study the risks and control mechanisms at work in regional and inter-municipal partnerships, or in collaborative arrangements between municipalities and societal service institutions.

Third, in both cases the public partner was inexperienced and unfamiliar with PPP initiatives. Although PPPs are relatively wide-spread in countries such as the U.S. and the U.K., they are relatively new in Belgium as in many other countries (Grimsey \& Lewis, 2005). Given the considerable resource constraints and/or knowledge limitations of the public partners in our cases, this may have opened an important space for project champions and conveners to play their role. Future research needs to investigate how organizational learning may impact and/or limit our findings with respect to project champions and conveners, in line with Batac and Carassus (2009). In particular, an interesting area for future research relates to the effects of purposive organizational learning structures set up by governments to actively acquire, disseminate, interpret and store knowledge for governing and managing future PPPs.

A fourth and last suggestion for future research relates to the study of political controls in a private setting. Although our findings are based on a comparative case study in a public-private setting, we suggest that they are also likely to be relevant to IORs in the private sector, since we believe that, besides relational and performance risk, socio-political risk stemming from patronage obstacles, the support needed by hierarchically superior agencies, turf protection and external pressure from stakeholder groups might also play an important role in a private sector setting. A thorough literature review related to private IOR settings provided us with evidence of the existence and role of socio-political risks in private relationships. Ke and Wei (2007) and Ke et al. (2009) for instance stress the importance of socio-political elements in explaining the willingness to share information between supply chain partners. External parties that may exert 
socio-political pressures on IORs include a firm's key customers, suppliers, competitors, other trading partners, parent corporations, regulatory bodies and government agencies. Ke et al. (2009) indicate that the pressures by these third parties can be exerted on the firm formally through contracts, rules or laws, or informally through certain social or cultural expectations based on, for instance, new practices in the market and fear of being left out of its industry. Interestingly, they also suggest that these pressures and expectations from third parties upon a firm may affect the firm's relationship with other partners and may therefore introduce additional risks into exchange relationships (Ke et al., 2009). Ke and Wei (2007) add that IORs might even exist because of certain socio-political forces, even if they are not cost-efficient. Similarly, we also found some evidence of the role of project champions and conveners in private IORs. In a context of inter-organizational information and communication systems, Kumar and Van Dissel (1996) stress that the current IOR literature focuses on reasons for inter-organizational collaboration primarily from a rational economic perspective. They assert that this economic perspective provides only a limited explanation of the inter-organizational phenomenon and needs to be complemented with socio-political considerations. In particular, they suggest that if the intended benefits of IOR collaborations are to be realized and sustained, 'corporate statesmen' are needed to nurture the cooperation by anticipating potential risks and managing them proactively. They also suggest that the personal chemistry and inter-action between corporate leaders or statesman have an important influence on whether or not an IOR will come into existence and mature. These corporate statesmen clearly correspond with the project champions in our framework. In addition, in a context of collaboration between competitors in R\&D alliances, Rindfleisch and Moorman (2003) suggest that the partners in such IORs may appeal to a neutral third-party monitor, such as a government agency or a university, to monitor the behaviour and mediate disagreements. Rindfleisch and Moorman (2003) see three important functions for these third parties: 1) they have no profit motive and can therefore serve a watchdog or monitoring function in the IOR, 2) they can infuse fresh ideas to stimulate the IOR collaboration, and 3) they can also serve as a neutral judge and facilitator to help resolve disagreements and build trust among alliance participants. These neutral third parties can therefore be regarded as the conveners in our framework. In sum, this evidence clearly indicates that socio-political risk and political controls like project champions and conveners may play an important role in private IORs. At the same time, the current private IOR literature tends to underestimate these influencing factors of inter-organizational interaction and has never systematically investigated them.

To conclude, we would like to stress that this paper contributes to the literature on management control in IORs by extending prior management control frameworks on IORs to include socio-political risks and political controls such as project champions and conveners. We suggest that these findings may not only be relevant for the success of public-private initiatives, which were the focus of this study, but also for private IORs that involve the cooperation among organizations with diverse missions, structures and cultures. Future research is required to find 
out whether we need to extend private IOR management control frameworks with the concepts introduced in this study. 


\section{References}

Abdel Aziz, A. 2007. Successful delivery of public-private partnerships for infrastructure development. Journal of Construction Engineering and Management, December 2007, 918-931.

Abednego, M.P., Ogunlana., S.O. 2006. Good project governance for proper risk allocation in public-private partnerships in Indonesia. International Journal of Project Management, 24, 622634.

Anderson, S.W., Dekker, H.C. 2005. Management control for market transactions: The relation between transaction characteristics, incomplete contract design and subsequent performance. Management Science, 51, 1734-1752.

Babiak, K.M. 2009. Criteria of effectiveness in multiple cross-sectoral interorganizational relationships. Evaluation and Program Planning, 32, 1-12.

Batac, J., Carassus, D. 2009. Interactions between control and organizational learning in the case of a municipality: A comparative study with Kloot (1997). Management Accounting Research, 20, 102-116.

Bloomfield, P. 2006. The challenging business of long-term public-private partnerships: reflections on local experience. Public Administration Review, March-April, 400-411

Brignall, S., Modell, S. 2000. An institutional perspective on performance measurement and management in the 'new public sector'. Management Accounting Review, 11, 281-306.

Broadbent, J., Laughlin. R. 2003. Public private partnerships: an introduction. Accounting, Auditing and Accountability Journal, 16, 332-341.

Chakrabarti, A. 1974. The role of champion in product innovation. California Management Review, $15,436-454$

Cooper, R. and Slagmulder, R., 2004. Interorganizational cost management and relational context. Accounting, Organizations and Society, 29, 1-26.

Court of Audit of Belgium (Rekenhof). 2009. Publiek-private samenwerking bij de Vlaamse overhead. Verslag van het Rekenhof aan het Vlaams Parlement. Brussel, Feb. 2009, 115p.

Das, T.K., Teng, B.S. 1996. Risk types and inter-firm alliance structures. Journal of Management Studies, 33, 827-843.

Das, T.K., Teng, B.S. 2001. Trust, control and risk in strategic alliances: an integrated framework. Organization Studies, 22, 251-283.

Dekker, H. C. 2003. Value Chain Analysis in Interfirm Relationships: A Field Study. Management Accounting Research, 14, $1-23$

Dekker, H.C. 2004. Control of inter-organizational relationships: Evidence on appropriation concerns and coordination requirements. Accounting, Organizations and Society, 29, 27-49.

Dekker, H.C., Van den Abbeele, A. 2009. Organizational learning and interfirm control: the effects of partner search and prior exchange experiences. Organization Science, forthcoming.

Donada, C., Nogatchewsky, G. 2006. Vassal or lord buyers: How to exert management control in asymmetric interfirm transactional relationships? Management Accounting Research, 17, 259287. 
Dorado, S., Vaz, P. 2006. Conveners as champions of collaboration in the public sector: A case from South Africa. Public Administration \& Development, 23, 141-150.

Dunoon, D. 2002. Rethinking leadership for the public sector. Australian Journal of Public Sector Management, 61, 3-18.

Eglene, O., Dawes, S.S., Schneider, C.A. 2007. Authority and leadership patterns in public sector knowledge networks. The American Review of Public Administration, 37, 91-113.

Eisenhardt, K.M. 1985. Control: Organizational and economic approaches. Management Science, 31, 134-149.

Eisenhardt, K.M. 1989. Building theories from case study research. Academy of Management Review, 14, 532-550.

Ferreira, L.D., Merchant, K.A. 1992. Field research in management accounting and control: a review and evaluation. Accounting, Auditing and Accountability Journal, 5, 4, 3-34.

Gephart, R. 2004. From the editors: Qualitative Research and the Academy of Management Journal. Academy of Management Journal, 47, 454-462.

Gil, N. 2009. Developing cooperative project client-supplier relations: how much to expect from relational contracts? California Management Review, 51, 144-169.

Goodman, L.A. 1961. Snowball sampling. Annals of Mathematical Statistics, 32, 148-170.

Gray, B., 1985. Conditions facilitating interorganizational collaboration. Human Relations, 38, 911 936.

Gray, B., Wood, DJ. 1991. Collaborative alliances: moving from theory to practice. Journal of Applied Behavioural Science, 27, 3-22.

Grimsey, D., Lewis, M.K. 2004. The governance of contractual relationships in public-private partnerships. Journal of Corporate Citizenship, 15, 91-109.

Grimsey, D., Lewis, M.K. 2005. Are Public Private Partnerships value for money? Evaluating alternative approaches and comparing academic and practitioner views. Accounting Forum, 29, 345-378.

Gulati, R., Singh, H. 1998. The architecture of cooperation: Managing coordination costs and appropriation concerns in strategic alliances. Administrative Science Quarterly, 43, 781-814.

Hodge, G.A., Greve, C. 2007. Public-private partnerships: an international performance review. Public Administration Review, May-June, 545-558.

Hood, C. 1991. A public management for all seasons. Public Administration, 69, 3-19.

Hood, C. 1995. The 'new public management' in the 1980s: variations on a theme. Accounting, Organizations and Society, 20, 93-119.

Howell, J.M., Higgins, C.A. 1990. Champions of technological innovation. Administrative Science Quarterly, 35, 317-341.

Humphrey, C., Scapens, R.W. 1996. Methodological themes: Theories and case studies of organizational accounting practices: limitation or liberation? Accounting, Auditing \& Accountability Journal, 9, 86-106. 
Javindan, M., Waldman, D.A. 2003. Exploring charismatic leadership in the public sector:

Measurement and consequences. Public Administration Review, 63, 229-242.

Jennings, E., Krane, D. 1994. Coordination and welfare reform: The quest for the philosopher's stone. Public Administration Review, 54, 341-348.

Johnston, J., Gudergan, S.P. 2007. Governance of public-private partnerships: lessons learnt from an Australian case? International Review of Administrative Sciences, 73, 569-582.

Kamminga, P.E., van der Meer-Kooistra, J. 2007. Management control patterns in joint venture relationships: A model and an exploratory study. Accounting, Organizations and Society, 32, $131-154$

Kalegaonkar, A., Brown, L.D. 2000. Intersectoral cooperation. Lessons from practice. IDR Reports $16(2)$.

Ke, W., Liu, H., Wei, K.K., Gu, J., Chen, H. 2009. How do mediated and non-mediated power affect electronic supply chain system adoption? The mediating effect of trust and institutional pressures. Decision Support Systems, 46, 839-851.

Ke, W., Wei, K.K. 2007. Factors affecting trading partners' knowledge sharing: Using the lens of transaction cost economics and socio-political theories. Electronic Commerce Research and Applications, 6, 297-308.

Klijn, E.H., Edelenbos, J., Kort, M., Van Twist, M. 2008. Facing management choices: an analysis of managerial choices in 18 complex environmental public-private partnership projects. International Review of Administrative Sciences, 74, 251-282.

Klijn, E.H., Teisman G.R. 2003. Institutional and Strategic Barriers to Public-Private Partnership: An Analysis of Dutch Cases. Public Money \& Management, 23, 137-146.

Kloot, L., 1997. Organizational learning and management control systems: responding to environmental change. Management Accounting Research, 8, 47-73.

Kumar, K., Van Dissel, H.G. 1996. Sustainable collaboration: Managing conflict and cooperation in interorganizational systems. MIS Quarterly, 20, 279-300.

Kwak, Y.H., Chih, Y., Ibbs, C.W. 2009. Towards a comprehensive understanding of public private partnerships for infrastructure development. California Management Review, 51, 51-78.

Langfield - Smith, K. 2008. The Relations between Transactional Characteristics, Trust and Risk in the Start-Up Phase of a Collaborative Alliance. Management Accounting Research, 19, 344 364.

Langfield - Smith, K., Smith D. 2003. Management Control Systems and Trust in Outsourcing Relationships. Management Accounting Research, 14, 281 - 307.

Lawler, J. 2008. Individualization and public sector leadership. Public Administration, 86, 21-34.

Lewicky, R.J., Weiss, S.E., Lewin, D. 1992. Models of conflict, negotiation and third party Intervention: A review and synthesis. Journal of Organizational Behavior, 13, 209- 252.

Lillis, A.M. 1999. A framework for the analysis of interview data from multiple field research sites. Accounting \& Finance, 39, 79-105. 
Lipe, M.G., Salterio, S.E. The balanced scorecard : judgmental effects of common and unique performance measures. The Accounting Review, 75, 3, 283-298.

Markham, S.K. 2000. Corporate championing and antagonism as forms of political behavior: an R\&D perspective. Organization Science 11, 429-447.

Markham, S.K., Aiman-Smith, L. 2001. Product champions: truths, myths, and management. Research Technology Management, 44, 44-50.

Mellors, J. 1996. Managing and leading in the next century. Australian Journal of Public Administration, 55 (3), 83-89

Miles, M.B., Huberman, A.M. 1998. Qualitative data analysis: an expanded sourcebook, $2^{\text {nd }}$ edition. Sage Publications, London.

Mohr, J., Spekman, R. 1994. Characteristics of partnership success: Partnership attributes, communication behavior, and conflict resolution techniques. Strategic Management Journal, 15: 135-152.

Mouritsen, J., Hansen, A., Hansen, C. O. 2001, Interorganizational controls and organizational competences: episodes around target cost management/functional analysis and open-book accounting. Management Accounting Research, 12, 221-244.

OECD. 2008. Public-private partnerships: in pursuit of risk sharing and value for money. GOV/PGC/SBO(2008)1/REV1, $91 \mathrm{p}$.

Otley, D.T., Berry, A.J. 1994. Case study research in management accounting and control. Management Accounting Research, 5, 45-65.

Ouchi, W.G. 1979. A conceptual framework for the design of organizational control mechanisms. Management Science, 25, 833-848.

Parker, D., Hartley, K. 2003. Transaction costs, relational contracting and public private partnerships: a case study of UK defence. Journal of Purchasing \& Supply Management, 9, 97108.

Rindfleisch, A., Moorman, C. 2003. Interfirm cooperation and customer orientation. Journal of Marketing Research, 40, 421-436.

Ryan, B., Scapens, R., Theobald, M., 2002. Research method and methodology in finance and accounting. Thomson, London.

Sako, M. 1992. Prices, quality and trust: inter-firm relations in Britain and Japan. Cambridge University Press Cambridge

Salganik, M.J. , Heckathorn, D.D. 2004. Sampling and Estimation in Hidden Populations Using Respondent-Driven Sampling. Sociological Methodology, 34, 193-239.

Saunders, M., Lewis, Ph., Thornhill, A. 2006. Research methods for business students, $4^{\text {th }}$ edition. Pearson Education.

Scapens R.W. 1990. Researching management accounting practice: The role of case study methods. British Accounting Review, 20, 259-281.

Schön, D. 1963. Champions for radical new inventions. Harvard Business Review, 41, 77-88. 
Selsky, J.W., Parker, B. 2005. Cross-Sector Partnerships to Address Social Issues: Challenges to Theory and Practice. Journal of Management, 31, 849-873.

Silverman, D. 2005. Doing Qualitative Research. Sage Publications, London.

Thompson, J. 1967. Organizations in action. McGraw-Hill, New York

Torres, L., Pina, V. 2001. Public-private partnership and private finance initiatives in the EU and Spanish local governments. European Accounting Review, 10, 601-619.

Van der Meer-Kooistra, J., Vosselman, E.G.J. 2000. Management control of interfirm transactional relationships: the case of industrial renovation and maintenance. Accounting, Organizations and Society, 25, 51-77.

Van der Meer - Kooistra ,J., Vosselman, E. G. J. 2006. Research on Management Control of Interfirm Transactional Relationships: Whence and Whither. Management Accounting Research, 17, 227 - 237

Van Gestel, K., Voets, J., Verhoest, K. 2009. Complexity and control: how do they work in a PPS? Paper presented at IRSPM XIII, Copenhagen Business School.

Vosselman, E. G. 2002. Towards horizontal archetypes of management control: a transaction cost economics perspective. Management Accounting Research, 13, 131-148.

Warner, M.E., Hefetz., A. 2008. Managing markets for public service: the role of mixed public/private delivery of city services. Public Administration Review, 68, 155-166.

Westley, F., Vredenburg, H. 1997. Interorganizational collaboration and the preservation of global biodiversity. Organization Science, 8, 381-403.

Wettenhall, R. 2003. The rhetoric and reality of public-private partnerships. Public Organisation Review: A Global Journal, 3, 77-107.

Williamson, O.E. 1985. The economic institutions of capitalism. Free Press, New York.

Williamson, O.E. 1991. Comparative economic organization: the analysis of discrete structural alternatives, Administrative Science Quarterly, 36, 269-296.

Yin, R.K. 2003.Case study research: Design and methods. Applied Social Research Methods Series. Sage Publications, London. 


\section{Figure 1: Theoretical framework}

Management Control of Public-Private Partnerships (PPPs)

\begin{tabular}{|c|c|c|c|}
\hline $\begin{array}{c}\text { PPP } \\
\text { characteristics }\end{array}$ & $\begin{array}{l}\text { Risks } \\
\text { involved }\end{array}$ & $\begin{array}{c}\text { PPP } \\
\text { organization }\end{array}$ & $\begin{array}{c}\text { Management control } \\
\text { instruments used }\end{array}$ \\
\hline $\begin{array}{l}\text { Task characteristics } \\
\text { - } \quad \text { Output measurability } \\
\text { - Task programmability } \\
\text { Public sector environment } \\
\text { - Communitylevel goals } \\
\text { - Alternating political parties } \\
\text { - in power } \\
\text { - Support needed from } \\
\text { hierarchically superior } \\
\text { institutions } \\
\text { - Turf protection } \\
\text { External pressure from } \\
\text { stakeholder groups }\end{array}$ & $\begin{array}{c}\text { RELATIONAL } \\
\text { RISK } \\
\text { PERFORMANCE } \\
\text { RISK } \\
\\
\text { SOCIO- } \\
\text { POLITICAL } \\
\text { RISK }\end{array}$ & LOOSE & $\begin{array}{l}\text { Outcome } \\
\text { controls } \\
\text { Behaviour } \\
\text { controls } \\
\text { Social } \\
\text { controls } \\
\\
\text { Political } \\
\text { Controls } \\
\text { * Project } \\
\text { champions } \\
\text { * Conveners }\end{array}$ \\
\hline
\end{tabular}


Table 1: Empirical data

\begin{tabular}{|c|c|c|c|}
\hline \multicolumn{4}{|c|}{ INTERVIEWS with key informants } \\
\hline Related to & Contact person & Organization & Duration \\
\hline Case $1 \& 2$ & Director & $\begin{array}{l}\text { Knowledge Centre PPP } \\
\text { Flanders }\end{array}$ & $1 \mathrm{~h}$ \\
\hline Case $1 \& 2$ & Managing director & Building group & $2 \mathrm{~h} 20+1 \mathrm{~h}$ \\
\hline Case 1 & Mayor & Major municipality & $1 \mathrm{~h} 35$ \\
\hline Case 1 & City Secretary & Major municipality & $1 \mathrm{~h} 40$ \\
\hline Case 2 & Architect & City development company & $1 \mathrm{~h} 20$ \\
\hline Case 2 & Director & City development company & Oh50 \\
\hline \multicolumn{4}{|c|}{ DOCUMENTS } \\
\hline Related to & Issued by & \multicolumn{2}{|c|}{ Type of documents analyzed } \\
\hline Case $1 \& 2$ & $\begin{array}{l}\text { Knowledge Centre } \\
\text { PPP Flanders }\end{array}$ & \multicolumn{2}{|c|}{$\begin{array}{l}\text { Website information on recent PPPs in Flanders, brochure instructing public } \\
\text { and private partners in terms of output specifications of PPP projects }\end{array}$} \\
\hline Case $1 \& 2$ & Building group & \multicolumn{2}{|c|}{$\begin{array}{l}\text { Powerpoint presentation for study day on successful PPPs in Flanders, } \\
\text { company magazines explaining the experiences with both cases, Website } \\
\text { information presenting the company and its projects }\end{array}$} \\
\hline Case 1 & $\begin{array}{l}\text { Knowledge Centre } \\
\text { PPP Flanders }\end{array}$ & \multicolumn{2}{|c|}{$\begin{array}{l}\text { Handbook on Design, Build, Finance and Maintain (DBFM) projects, model } \\
\text { contract for Design, Build and Finance (DBF) projects }\end{array}$} \\
\hline Case 1 & Municipality & \multicolumn{2}{|c|}{$\begin{array}{l}\text { Research report DBFM swimming pools in Flanders, Brochure informing the } \\
\text { local citizens, Business plan of the private partners, Statutes of the } \\
\text { Interlocal Association, Housekeeping rules of the Interlocal Association, } \\
\text { Territory concession agreement, Financial Guarantee agreement towards } \\
\text { private partners, Side letter VAT arrangement building, Execution } \\
\text { agreement between municipalities and private partners, Minutes of the city } \\
\text { council including PPP budgets }\end{array}$} \\
\hline Case 2 & $\begin{array}{l}\text { Knowledge Centre } \\
\text { PPP Flanders }\end{array}$ & \multicolumn{2}{|c|}{ Brochure on urban renewal projects } \\
\hline Case 2 & $\begin{array}{l}\text { City Development } \\
\text { Company }\end{array}$ & \multicolumn{2}{|c|}{$\begin{array}{l}\text { Annual report of the City Development Company, Powerpoint presentation } \\
\text { on practical execution of PPP projects, Website information on city } \\
\text { regeneration project, Declaration of intent for establishing a cooperation } \\
\text { agreement, Final Cooperation Agreement between the Building group and } \\
\text { the City Development Company, Establishment Act of the special purpose } \\
\text { PPP Limited Company, Contractors' contract for the city regeneration } \\
\text { project, Shareholders' agreement for the PPP Limited Company }\end{array}$} \\
\hline
\end{tabular}


Table 2: Analysis of the cases

Panel A: Content and nature of the cases

\begin{tabular}{|l|l|l|}
\hline \multicolumn{1}{|c|}{$\begin{array}{c}\text { Swimming pool project } \\
\text { Content of the PPP }\end{array}$} & \multicolumn{1}{c|}{$\begin{array}{c}\text { Case 2: } \\
\text { Urban regeneration project }\end{array}$} \\
\hline Public parties involved & $\begin{array}{l}\text { Long-term infrastructure project } \\
-\quad \text { Public property } \\
\text { DBFMO (Design Build Finance } \\
\text { Maintain Operate) }\end{array}$ & $\begin{array}{l}\text { Urban renewal and downtown } \\
\text { economic development } \\
\text { Private property } \\
\text { Design \& Build (DB) }\end{array}$ \\
\hline Private parties involved & $\begin{array}{l}\text { Interlocal Association of two adjacent } \\
\text { municipalities, aiming to offer cheap } \\
\text { swimming facilities to schools }\end{array}$ & $\begin{array}{l}\text { City development company of one } \\
\text { municipality, aiming to revive an } \\
\text { impoverished neighbourhood in the } \\
\text { city centre }\end{array}$ \\
\hline & $\begin{array}{l}\text {-Building Group for the construction } \\
\text {-Private consortium (including the } \\
\text { Building Group) for the exploitation, } \\
\text { aiming to run a profitable sports } \\
\text { complex. }\end{array}$ & $\begin{array}{l}\text { Building Group: involved in the } \\
\text { regeneration and construction parts } \\
\text { of the project, aiming for a financially } \\
\text { interesting projects and for getting } \\
\text { known in the region as a solid partner } \\
\text { in a PPP context }\end{array}$ \\
\hline
\end{tabular}

Panel B: PPP characteristics and risks involved

\begin{tabular}{|c|l|l|}
\hline & \multicolumn{1}{|c|}{$\begin{array}{c}\text { Case 1: } \\
\text { Task characteristics }\end{array}$} & \multicolumn{1}{c|}{$\begin{array}{c}\text { Case 2: } \\
\text { Urban regeneration project }\end{array}$} \\
\hline - Output measurability & $\begin{array}{l}\text { High: providing school swimming } \\
\text { (obligation for municipalities); } \\
\text { additional facilities were gradually } \\
\text { added by the private consortium }\end{array}$ & $\begin{array}{l}\text { Initially low: further development of } \\
\text { the plans was inherent to the PPP } \\
\text { cooperation; later on, more concrete } \\
\text { plans for shop keeping and housing } \\
\text { were formulated }\end{array}$ \\
\hline $\begin{array}{c}\text { Knowledge of } \\
\text { transformation process }\end{array}$ & $\begin{array}{l}\text { Clear for the private partner, not } \\
\text { clear for the public partner }\end{array}$ & $\begin{array}{l}\text { Initially not clear for both parties } \\
\text { involved: creativity and interaction } \\
\text { between all parties was needed }\end{array}$ \\
\hline Relational risk & $\begin{array}{l}\text { Low because of low degree of } \\
\text { involvement between public and } \\
\text { private partners }\end{array}$ & $\begin{array}{l}\text { High because of high degree of } \\
\text { interaction involving all partners }\end{array}$ \\
\hline Performance risk & $\begin{array}{l}\text { High because only outcomes would } \\
\text { be measured and it was not clear } \\
\text { whether the private partner would be } \\
\text { able to meet the requirements. }\end{array}$ & $\begin{array}{l}\text { High because of the uncertain } \\
\text { success of the urban regeneration } \\
\text { initiative, and because of the } \\
\text { significant financial risk }\end{array}$ \\
\hline $\begin{array}{l}\text { Public environment } \\
\text { characteristics and according } \\
\text { socio-political risk }\end{array}$ & $\begin{array}{l}\text { Divergent goals: crisis between } \\
\text { public and private partners, support } \\
\text { needed from hierarchically superior } \\
\text { government agency, turf protection: } \\
\text { radical change in mentality required } \\
\text { by municipal employees, need to } \\
\text { deal with citizens from two different } \\
\text { municipalities, new way of } \\
\text { cooperation between the } \\
\text { municipalities: Interlocal Association }\end{array}$ & $\begin{array}{l}\text { Diverging goals: crisis between } \\
\text { public and private partners, } \\
\text { procedures installed by } \\
\text { hierarchically superior government } \\
\text { agency influenced the set-up of the } \\
\text { special purpose PPP Company, } \\
\text { external pressure from stakeholder } \\
\text { groups: real estate developers and } \\
\text { citizens. }\end{array}$ \\
\hline
\end{tabular}


Panel C: PPP organization and management control instruments used

\begin{tabular}{|c|c|c|}
\hline & $\begin{array}{c}\text { Case 1: } \\
\text { Swimming pool project: }\end{array}$ & $\begin{array}{c}\text { Case 2: } \\
\text { Urban regeneration project: }\end{array}$ \\
\hline Organizational relationship & $\begin{array}{l}\text { Loose: The public partner delegated } \\
\text { the tasks to the private consortium }\end{array}$ & $\begin{array}{l}\text { Tight: Public and private partners set } \\
\text { up a separate special purpose PPP } \\
\text { Company }\end{array}$ \\
\hline \multicolumn{3}{|l|}{$\begin{array}{l}\text { Management control } \\
\text { instruments used }\end{array}$} \\
\hline Outcome control & $\begin{array}{l}\text {-Contract: central management } \\
\text { control instrument, lot of time spent } \\
\text { on preparing the contract }\end{array}$ & $\begin{array}{l}\text {-Contract: based on feasibility study } \\
\text { and basis for the cooperation } \\
\text { agreement. No concrete use during } \\
\text { the further process }\end{array}$ \\
\hline Behaviour control & $\begin{array}{l}\text { - Yearly meetings of Interlocal } \\
\text { Assocation with private consortium }\end{array}$ & $\begin{array}{l}\text {-Meetings of the Special Purpose } \\
\text { PPP Company: } \\
\text { - } \quad \text { Weekly yard meetings } \\
\text { - } \quad \text { Executive Committee } \\
\text { - } \quad \text { Board } \\
\text {-Open book accounting }\end{array}$ \\
\hline Social control & $\begin{array}{l}\text { - Public tender proposals judged by } \\
\text { various committees } \\
\text { - Trust between the municipalities } \\
\text { and the private parties after one } \\
\text { distrusted private party fell off. }\end{array}$ & $\begin{array}{l}\text { - Meetings of the Special Purpose } \\
\text { PPP Company created amiable } \\
\text { atmosphere during whole process } \\
\text {-Trust between the City } \\
\text { Development Centre and the } \\
\text { Building Group based on the public } \\
\text { tender judgment (selection process) } \\
\text { and the Building Group's experience } \\
\text { with PPP. } \\
\text { - Trust increased after the significant } \\
\text { downsizing of the project. }\end{array}$ \\
\hline \multicolumn{3}{|l|}{ Political control } \\
\hline - $\quad$ Project champions & $\begin{array}{l}\text {-Mayor of the major municipality, } \\
\text { being a lawyer experienced in } \\
\text { concessions } \\
\text {-Managing Director of the Building } \\
\text { Group }\end{array}$ & $\begin{array}{l}\text {-Managing Director of the Building } \\
\text { Group played a crucial role during } \\
\text { the crisis } \\
\text {-Mayor (a lawyer) as the chair of the } \\
\text { special purpose PPP company }\end{array}$ \\
\hline $\begin{array}{ll}- & \text { Conveners }\end{array}$ & $\begin{array}{l}\text {-Lawyers specialized in public sector } \\
\text { projects } \\
\text {-Knowledge Centre PPP Flanders }\end{array}$ & $\begin{array}{l}\text {-Independent shareholder of the } \\
\text { Special Purpose PPP } \\
\text {-Independent coordinator at the yard } \\
\text {-Local real estate agents } \\
\text {-Independent architectural firm } \\
\text {-Knowledge Centre PPP Flanders }\end{array}$ \\
\hline
\end{tabular}

